\title{
The Survival of the Bajo Language Maritime Lexicon on the Tinanggea Coast of Konawe Selatan Regency
}

\author{
Aris Badara ${ }^{1}$ La Yani Konisi ${ }^{2}$, Amiruddin Rahim ${ }^{3}$, La Ode Sahidin ${ }^{4}$, Marwati marwati ${ }^{5}$ \\ \{arisbadara71@yahoo.co.id ${ }^{1}$ layanikonisi@gmail.com², amirudinrahim@yahoo.co.id ${ }^{3}$, \\ sahidinlaode@ymail.com4, marwatianwar1945@gmail.com ${ }^{5\}}$ \\ Halu Oleo University, Kampus Hijau Bumi Tridharma, Anduonohu, Kec. Kambu, Kota Kendari, \\ Provinsi Sulawesi Tenggara 93232, Indonesia ${ }^{1,2,3,4,5}$
}

\begin{abstract}
Currently, 50\% of regional languages around the world face the threat of extinction. If this happens, then the community will lose the source of knowledge. Therefore, regional languages need serious attention, especially through in-depth research. One of the contributions of this research to this is to reveal the survival of the Bajo language maritime lexicon on the Tinenggea Coast and the factors that influence its survival. The data source of this research is sourced from the lexicon competency test which is analyzed quantitatively. The results showed that the Bajo language on the Tinanggea Coast still survived with a 96\% survival rate. The factors that cause the Bajo survival in the Tinanggea Coast are natural environment and social environment which are still maintained.
\end{abstract}

Keywords: maritime lexicon, Bajo language, ecolinguistics, tinaggea coast,

\section{Introduction}

Unesco predicted that $50 \%$ of the 6,700 languages in the inner world would experience extinction [1]. Therefore, it is time for local languages to get serious attention from various groups both government, linguists and language lovers. One of the factors causing the threat of regional languages is the change in the environment. When the environment changes and is damaged, the vocabulary in that language goes extinct.

The importance of maintaining local languages is because regional languages are the support of culture. Therefore, it is time for regional languages, including Bajo languages in the Coastal District of Tinenggea, South Konawe District, Southeast Sulawesi Province to be preserved and preserved. That is because regional languages are an invaluable part of human assets. Besides, the loss of regional languages will cause poverty as a source of knowledge for the community [2]. As one of the regional languages in Indonesia, Bajo plays an important role in daily interactions as a communication tool for the user community. Although until now the Bajo language still has a relatively large number of speakers, it does not guarantee that the language can withstand the threat of extinction. The reason is to survive, the language must be firmly in the speaker's cognition and must be used more often and deeply in the socio-cultural life of its people [3].

At present, the use of Bajo in the younger generation of Bajo communities has begun to decrease because most have shifted to using Indonesian [4]. Another cause is a change in culture, from traditional culture to modern culture or a change in an area, from rural areas to 
urban areas. Also, it is caused by the loss of several lexicon icons that are related to maritime as an environment that is close to the Bajo community life. Likewise, in several types of marine fish that are no longer found on the Tinanggea Coast due to silting of the sea, the use of fish bombs by the Bajo people has caused sea corals to be damaged. This condition is very worrying because it can destroy the Bajo lexicons, especially the maritime lexicon. Found on the Tinanggea Coast many marine tools are new and modern which led to the birth of new terms. There are also some terms or eco-lexicons that have disappeared and become extinct together with the loss of maritime icons [5]. These conditions will affect the burial of all cultural values stored in the language, including various environmental wisdom.

As an ecolinguistic study, this research views the language and community of its speakers as seen as organisms that live systematically in life with other organisms. Furthermore, [6] argues that human time and effort determine the preservation of a regional language. Whatever is used by the older generation is solely to maintain the local language to remain sustainable from the threat of extinction. Based on the description above, this research is focused on the survival conditions of the Bajo language maritime lexicon on the Tinenggea Coast and the factors that influence its survival.

\section{Theoretical review}

Ecolinguistics is an interdisciplinary study between ecology and linguistics. The discipline of science examines the interrelationships between language and the social environment. In line with this argues that ecolinguistic studies are interrelationships of language and environment, physical and social environment, and diversity [7]. Based on these two opinions, it is distinguished between ecological studies and ecolinguistic studies. Ecological studies include environmental dependence in a system. While ecolinguistic studies examine the concepts of ecology and the environment, conservation, interaction, and systems in a language.

Ecolinguistics also highlights human and cultural resources concerning verbal symbolization in regional languages. This includes the use of words or terms as a mirror of the social environment and the natural environment of humans and humans, humans and nature around them. In ecolinguistic studies, the term 'language environment' includes the physical and social environment. The physical environment concerns geography which consists of the physical environment or topography of a country (coastal, valleys, land, plateau, mountain), climate, and rainfall intensity, human life consisting of fauna, flora, and mineral resources. The social environment consists of various community forces that shape the minds and lives of every individual including religion, ethics, forms of political organization, and art.

The existence of language is related to the question of whether a language is still known or unknown to the public. It is still known that the language is still used in everyday communication interactions by its speakers. On the contrary, if the language is no longer known then it is no longer used every day as a communication tool. The process occurred because of the function of language as a unifying or separatist self from other groups. Suggests that a person unconsciously maintains his language. According to Fasold, language has a function as contrastive self-identification, constructive self-identification, namely language functions as a tool to unite or separate themselves from other groups [8]. Language survival is related to social and psychological factors, such as the strength of ethnic ties, value systems, settlement patterns, religion, family systems, gender, and economy [10]. 
Other factors that influence language survival are position, social status, social position, age, and ethnicity. In addition to social factors, situational factors, such as interlocutors, topics, and communication situations also determine [9]. The ability of language to survive is influenced by three components, namely (a) the status of a language that is reflected in its attitude to its language, (b) the size of the speaker group and its distribution, and (c) institutional support for the language [10].

One of the phenomena that trigger language shifts is caused by the reduction in the number of young speakers of the language because they tend to use other languages that they consider to have prestige [11]. States that the main reason for language extinction is because parents no longer teach mother tongue to their children and no longer actively use regional languages at home [12]. Furthermore, that language can be analogous to organic creatures that have a "natural" age range. This opinion explains that language will die naturally, also there is a language that died because it was killed.

Another opinion that is now accepted is that language has a certain age, it depends on the user. It is they who determine whether language survives or not. Precisely, it is their ethnolinguistic vitality that determines. That language maintenance or language maintenance is an effort to keep a language used and valued, especially as a group identity, in the language community concerned through learning, literature, mass media, and others [13]. The preservation of a language is a consequence of a choice made by a group of language users. Retention of language, group (group) collectively determines to continue using language that is commonly used [14]

A lexicon is a language component that contains all information about the meaning and usage of words in a language; the wealth of words that a language has. Distinguishes the lexicon and the vocabulary. According to him, "the lexicon includes components that contain all information about words in a language such as semantic behavior, syntax, morphology, and phonology. The vocabulary is more emphasized on the wealth of words owned by someone or something language. The same opinion with Sibarani regarding the lexicon put forward, namely "the lexicon specifies the properties of each word, its phonological form, its morphological and syntactic properties, and meaning."

Lexicon is also called vocabulary or vocabulary. The lexicon is a language component that contains information about the meaning and usage of words in the language [15]. That vocabulary reflects the physical environment and human social environment. The complete vocabulary of a language is seen as a complex inventory consisting of designs arranged in the minds of the speech community. The vocabulary reflects the limits of the physical environment and the cultural character of the people who use it. Ecolexicon is a set of words that describe the conditions of the biotic environment (flora and fauna) and the abiotic (eg rocks, clay, water) of a language region that lives and is used.

Provide limits on the understanding of the lexicon as follows. Lexicon are: (a) the set of all the words and idioms of any language, (b) a dictionary, (c) the words and phrases listed in the base component of a generative grammar and information about them, (d) a mental system which contains all the information a person knows about words. According to psycholinguists, people 's knowledge of a word includes: (i) knowing how a word is pronounced, (ii) the grammatical patterns with which a word is used (iii) the meaning or meaning of the word. From the above understanding, it can be said that the lexicon has the meaning as (a) a series of words or expressions from a particular language, (b) a dictionary, (c) words or phrases that are registered based on generative grammar components and all information related to said words or phrases, and (d) a mental system consisting of all information that people know about words. According to psycholinguists, human knowledge about words includes: (a) knowing 
how the word is pronounced, (b) grammatical rules related to the word used, (c) the meaning or meaning of the word.

\section{Research methods}

This research was conducted in the period June to December 2018 which was carried out in the Tinenggea Coast, Tinanggea District, Konawe Selatan Regency, Southeast Sulawesi Province. The approach of this research is the qualitative and quantitative approach. This approach describes in-depth about oral data relating to the factors that influence the dynamics of the development of the Bajo language maritime lexicon on the Tinanggea Coast. Also, a quantitative approach is used to analyze the quantity of knowledge and understanding of the Bajo language maritime lexicon in the Bajo people who inhabit the Tinanggea Coast.

The subject of this research is focused on all levels of Bajo people who live in the Coastal District of Tinanggea, Konawe Selatan District. The number of respondents is 20 people were selected by purposive sampling that filled out a questionnaire containing 50 lists of Indonesian maritime lexicon. There are 2 instruments used, namely: (a) instrument A and (b) instrument B. Instrument A is a list of maritime lexicon entries to find out whether the lexicon is still used by respondents. The instrument $\mathrm{B}$ is intended to obtain data about the factors that cause the survival and unsustainability of the Bajo language maritime vocabulary on Tinenggea Coast, Konawe Selatan Regency.

Data collection focuses on natural settings or natural conditions using tests, observations, interviews, documentation, photos, pictures, and informal conversations. Besides, data collection techniques that are suitable to the needs of this study are also used in the form of a lexicon competency test, a test to test the level of maritime lexicon knowledge. Presentation of the results of data analysis using informal methods is a method of presenting data in the field of linguistics that presents data narratively. Presentation of the results of data analysis in this study also uses deductive and inductive techniques so that the presentation of this research is not monotonous. The deductive technique is a way of presenting by expressing things that are general then followed by the presentation of things that are specific as an explanation. The inductive technique is a way of presenting specific things and then general things are stated.

Data obtained from interviews, lexicon competency tests, observations, and documentation are separated by lexicon groups and broken down into units, to make conclusions. Furthermore, the data were analyzed using qualitative methods that describe the knowledge and understanding of the maritime lexicon of the Bajo community on the coast of Tinanggea District under reality. Quantitative data analysis is used to deduce the level of comprehension and survival of individual vocabulary used the following formula.

$$
\frac{\text { the number of maritime vocabulary survēving by respondents }}{\text { maritime vocabulary amount }} X 100 \%
$$

Vocabulary is categorized to survive if the respondent's vocabulary level is above $50 \%$. As for knowing the overall survival of the vocabulary used the following formula.

the number of manitime vocabulary surviving by respondents maritime vocabulary amount $x 100 \%$ 
Based on the formula above, Bajo language vocabulary is declared to survive if the total number of maritime vocabulary survives reaches $50 \%$ or more of the total maritime vocabulary.

\section{Result and discussion}

There are no references that mention about when the Bajo tribe began to inhabit the coast of Tinanggea Subdistrict, South Konawe Regency, Southeast Sulawesi. However, to date, the Coastal District of Tinanggea, Konawe Selatan Regency, is fully inhabited by the Bajo tribe with a total of 231 families (Bungin Village Profile 2018). As a community close to the sea, $95 \%$ of the population in the village of Bungin work as fishermen. The rest work as civil servants. In detail, the following is the data on the number of mastery per respondent group. The mastery shows the survival of the Bajo language maritime lexicon on the coast of Tinenggea, Konawe Selatan Regency, Southeast Sulawesi Province.

Table 1. Lexicon controlled by 100 of respondents

\begin{tabular}{|c|c|}
\hline Bajo vocabulary & English vocabulary \\
\hline Dilao & the sea \\
\hline Goya & Waves \\
\hline Libbu & Mud \\
\hline Lalang & In \\
\hline Maseng & Salty \\
\hline Palanto & Floating \\
\hline Daya & Fish \\
\hline Karama & Crab \\
\hline Doah & Prawn \\
\hline Kende & Squid \\
\hline Bale & Sea Cucumber \\
\hline Bangkau & Mangrove \\
\hline Agara & Jelly \\
\hline Lumut & Mildew \\
\hline Tuho & Sago palm leaves \\
\hline Daya tuna & Tuna fish \\
\hline Daya kariu & Shark \\
\hline Daya pai & Stingray \\
\hline Empe & Jarring \\
\hline Ringgi & Trawl \\
\hline Pissi & Fishing line \\
\hline Lipe & Boat \\
\hline Kappal & Ship \\
\hline Kappal kayu & Vessel ship \\
\hline Tiram & Oyster \\
\hline
\end{tabular}


Table 2. Lexicon controlled by $95 \%$ of respondents

\begin{tabular}{cc}
\hline Bajo vocabulary & English vocabulary \\
\hline Pangiri & Low tide \\
Guso & Sand \\
Lubbangang & River \\
Lola & Loai snail \\
\hline
\end{tabular}

Table 3: Lexicon controlled by $90 \%$ of respondents

\begin{tabular}{cc}
\hline Bajo vocabulary & English vocabulary \\
\hline Pasolong & Tide \\
Kutta & Octopus \\
Jollor & Boat \\
La'ma & Sail \\
\hline
\end{tabular}

Table 4. Lexicon controlled by $85 \%$ of respondents

\begin{tabular}{cc}
\hline Bajo vocabulary & English vocabulary \\
\hline Ngindas abal & Ngindas abal \\
Patindeng & Drowning \\
Daya gurami & Gouramy \\
Busai & Paddle \\
\hline
\end{tabular}

Table 5. Lexicon is controlled by $80 \%$ of respondents

\begin{tabular}{cc}
\hline Bajo vocabulary & English vocabulary \\
\hline Titinna & Superficial \\
Kappal patindeng & Kappal patindeng \\
\hline
\end{tabular}

Table 6. Lexiculture controlled by $75 \%$ of respondents

\begin{tabular}{cc}
\hline Bajo language & English vocabulary \\
\hline Lalang dilao & Seabed \\
Tinga dilao & Middle of the sea \\
Kaloma & Sea slug \\
\hline
\end{tabular}

Table 7. Lexicons controlled by $70 \%$ of respondents

\begin{tabular}{cc}
\hline Bajo vocabulary & English vocabulary \\
\hline Keru & Cloudy \\
Abal & Stream \\
Panuh & washed away \\
Koa gariggi & mangrove shells \\
Koa keluang & stone shells \\
\hline
\end{tabular}

Table 8. Lexicon controlled by $55 \%$ of respondents

\begin{tabular}{cc}
\hline Bajo Language & English vocabulary \\
\hline Ngindas goya & Storm \\
\hline
\end{tabular}


Table 9. Lexicon controlled by $45 \%$ of respondents

\begin{tabular}{cc}
\hline Bajo Language & English vocabulary \\
\hline Iga tabbe & Beach cliffs \\
Koa ndue & White sand shells \\
\hline
\end{tabular}

From the above table, tables 1 to table 8 show that the Bajo language in the Tinanggea Coast still has a survival status because it is still at a $96 \%$ survival rate. While the maritime lexicon does not survive, there are only $2(6 \%)$ as in table 9 . This is inversely proportional to the maritime lexicon of regional languages in Southeast Sulawesi Province. For example, the Moronene language maritime lexicon and Bajo language maritime lexicon in the Coastal District of Kolaka the survival rate of the Moronene lexicon is only $27.50 \%$. While the Badara research report states that the Bajo language survival rate in the Coastal District of Kolaka also has not survived because it is at a resistance level of $46,25 \%$.

The results showed that 2 factors caused the survival of the Bajo language maritime vocabulary on the coast of Tinanggea, namely the natural environment and social environment. The natural conditions on the coast of Tinenggea Subdistrict are still maintained so that the referents of plants, animals that exist in the marine environment, and traditional fishing gear are generally still present and are widely found and alive or growing. Likewise with the geographical conditions that are still surrounded by the sea so that most Bajo people work as Seamen. As such, they are still very familiar with the maritime lexicon.

The social environment that influences the survival of Bajo vocabulary is as follows: (1) Bajo Community Livelihoods. Bajo people on the coast of Tinanggea Subdistrict still depend their lives on the sea, both fish and marine products (plants and animals). The sea products, they use as food and medicine. Thus, the maritime lexicon is still conceptualized in their cognition, (2) Language Loyalty, Bajo people in general still have language loyalty. In general, in daily communication, they still use the Bajo language. In fact, in the Bajo community, it becomes a gesture if they use the language Bajo to parents, and (3) Conservative Behavior of Bajo community towards the Marine Environment, Bajo people on the coast of Tinanggea Subdistrict, also have conservative behavior, which is a behavior that has a tendency to be familiar with the environment so that the environment is not extinct and remains durable. For example through traditional ceremonies.

\section{Conclusion}

The Bajo lexicon of the Bajo language on the Tinanggea Coast is still in a $96 \%$ survival status. This is caused by factors: Bajo Language is still used in the family environment, Bajo people have language loyalty, the coastal environment is still well preserved and used as a source of life, and the existence of conservative behavior in the community Bajo.

\section{References}

[1] S. Mardiyati, Dasi Sigab (Dalang Siswa Siap Siaga Bencana): Model Pendidikan Kebencanaan Sebagai Ekstrakurikuler Berbasis Kearifan Lokal Di Daerah Rawan Bencana Di Indonesia. Semarang: Unnes, 2017.

[2] I. Widjana, Sosiolinguistik: Kajian Teori dan Analisis. Yogyakarta: Pustaka Pelajar, 2006.

[3] A. M. Mbete, "Problematika Keetnikan dan Kebahasaan dalam Perspektif Ekolinguistik.," 2009, p. 3. 
[4] T. Anderson, Pelestarian dan Pengembangan Bahasa Moronene. Baubau: Kantor Pusat Bahasa Sulawesi Tenggara), 2010.

[5] A. Adisaputra, Ancaman terhadap Kebertahanan Bahasa Melayu Langkat. Denpasar, Bali: Universitas Udayana, 2010.

[6] M. Rahardjo, "Language And Power: A Close Look At Critical Sociolinguistics.," Language And Power: A Close Look At Critical Sociolinguistics., 2004. [Online]. Available: www.mudjiarahardjo.com. . [Accessed: 14-Jun-2019].

[7] A. Fill, The Ecolinguistics Reader Language, Ecology and Environment. London: Continuum., 2001.

[8] R. Fasold, The Sociolinguistic of Society. New York: Blackwell., 1986.

[9] J. A. Fishman, The Sociology of Language. Massachusetts: Newbury House Plublication Gagasan Fishman., 1968.

[10] J. Holmes, An Introduction to Sociolinguistic. London: Longman Inc., 2001.

[11] G. Sudaryono, Tata Bahsa Praktis Bahasa Indonesia. Jakarta: Rineka Cipta, 2012.

[12] S. Ghufron, Pembentukan Kata dalam Bahasa Indonesia. Jakarta: Gramedia Pustaka utama, 2009.

[13] Widodo, Pemertahanan Bahasa Ibu Melalui Pendidikan Formal. Jakarta: Gramedia Pustaka utama, 2009.

[14] Sumarsono, Sosiolinguistik. Yogayakarta: Pustaka Pelajar, 2009.

[15] G. Booij, The Grammar of Words: An Introduction to Linguistic Morphology. Great Britain: Oxford University Press, 2007. 


\section{Appendix: Bajo Language Maritime Vocabulary}

\begin{tabular}{|c|c|c|}
\hline No & Bajo Language Maritime Vocabulary & English \\
\hline 1 & Dilao & The sea \\
\hline 2 & Goya & Waves \\
\hline 3 & Pasolong & High Tide \\
\hline 4 & Pangiri & Low tide \\
\hline 5 & Limpu & Mire \\
\hline 6 & Ngindas abal & Heavy current \\
\hline 7 & Titinna & Shallow \\
\hline 8 & Guso & Sand \\
\hline 9 & Lalang dilao & Seabed \\
\hline 10 & Tinga dilao & Tengah laut \\
\hline 11 & Patindeng & $\operatorname{sink}$ \\
\hline 12 & Lalang & within \\
\hline 13 & Keru & turbid \\
\hline 14 & Iga tabbe & Beach cliffs \\
\hline 15 & Abal & stream \\
\hline 16 & Ngindas goya & Storm \\
\hline 17 & Maseng & salted \\
\hline 18 & Lubbangang & River \\
\hline 19 & Kappal patindeng & Sinking ship \\
\hline 20 & Palanto & Floating \\
\hline 21 & Pano & floatoff \\
\hline II & Vocabulary related to sea shells & \\
\hline 22 & Koa gariggi & Mangrove scallops \\
\hline 23 & Koa ndue & White sand shells \\
\hline 24 & Koa keluang & Stone Shells \\
\hline 25 & Kaloma & Stone slug \\
\hline 26 & Tirang & Oyster \\
\hline 27 & Lola & Lola snails \\
\hline III & Vocabulary related to sea animals & \\
\hline 28 & Daya & Fish \\
\hline 29 & Karama & Crab \\
\hline 30 & Do" $a$ & Prawn \\
\hline 31 & Kende & Enemy spy \\
\hline 32 & Kutta & Octopus \\
\hline 33 & Bale & Sea Cucumber \\
\hline IV & Vocabulary related to sea plants & \\
\hline 34 & Bangkau & Mangrove \\
\hline 35 & Agar & Jelly \\
\hline 36 & Lumuk & mildew \\
\hline 37 & Tuho & Thatched leaves \\
\hline $\mathrm{V}$ & Vocabulary related to the fish name & \\
\hline 38 & Daya tuna & Tuna fish \\
\hline 39 & Daya gurami & Gouramy \\
\hline 40 & Daya Kareo & Shark \\
\hline 41 & Daya pai & Stingray \\
\hline VI & Vocabulary related to fishing equipment & \\
\hline 42 & Empe & Toil \\
\hline 43 & Ringgi & Trawl \\
\hline 44 & Pissi & Fishing line \\
\hline
\end{tabular}




\begin{tabular}{ccc}
\hline VII & Vocabulary related to marine vehicles & \\
\hline 45 & Jollor & Boat \\
46 & Lipe & Boat \\
47 & Kappal & ship \\
48 & Kappal kayu & Wooden ship \\
49 & La"ma & sail \\
50 & Busai & Paddle \\
\hline
\end{tabular}

